\title{
Characterization of Melon necrotic spot virus Isolated from Muskmelon
}

\author{
Gug-Seoun Choi*, Jae-Hyun Kim and Jeong-Soo Kim \\ National Horticultural Research Institute, Rural Development Administration, Suwon 441-440, Korea
}

(Received on January 11, 2003; Accepted on April 14, 2003)

\begin{abstract}
A severe disease of muskmelon (Cucumis melo cv. Alsnight) grown on rockwool in a plastic house was characterized by leaf and stem necrosis followed by death of the plants. In 2001, an isolate of Melon necrotic spot virus-MN (MNSV-MN) of the genus Carmovirus was identified as the causal agent of the disease on the basis of biological reactions and nucleotide sequence analyses of coat protein (CP) gene. MNSV-MN induced necrotic local lesions on mechanically inoculated leaves and systemic necrotic spots on the upper leaves of melon cvs. Alsnight, Rui III, Party, Imperial, and Seolhang. However, the inoculated leaves of watermelon and cucumber showed only necrotic lesions. DSRNAs extracted from the melon infected with MNSV-MN were separated into three components. Molecular sizes of the dsRNAs were estimated at approximately $4.5,1.8$, and $1.6 \mathrm{kbp}$. The amplified cDNA products of CP gene for MNSV-MN by RT-PCR showed approximately 1.2 kbp. The amplified DNA was digested to three fragments by MspI treatment. The cDNA of the genomic RNA of MNSV-MN was cloned and the region deduced to encode the $\mathrm{CP}$ was sequenced. The $\mathrm{CP}$ coding region, located near $3^{\prime}$ end of the genome, consisted of 1,170 nucleotides and had the potential to encode a 390 amino acid protein. The nucleotide and amino acid sequences of MNSV-MN CP gene were 84.0-94.6\% and 90.894.9\% identical with other MNSV isolates found in the GeneBank database, respectively. This is the first report on the occurrence of MNSV in Korea.
\end{abstract}

Keywords : Carmovirus, coat protein, identification, Melon necrotic spot virus, muskmelon, sequence.

Melon necrotic spot virus (MNSV) is a member of the genus Carmovirus. This genus, together with the genera Tombusvirus and Necrovirus, composes the Tombusviridae, a family of plant viruses with monopartite, single-stranded RNA genomes (Van Regenmortel et al., 2000). MNSV was previously shown to share certain physico-chemical characteristics with several unclassified, small, isometric plant viruses, as well as with carmoviruses and tombus-

\footnotetext{
*Corresponding author.

Phone) +82-31-290-6224, FAX) +82-31-295-9548

E-mail) choigs@ rda.go.kr
}

viruses (Morris and Carrington, 1988; Morris and Dodds, 1979). Nucleotide sequence data showed that these two groups of viruses were closely related (Rochon and Tremaine, 1989). In the nucleotide sequences of the genomes of two Japanese MNSV isolates, NH and NK, the open reading frames (ORFs) in both genomes encode five proteins: p29 (the pre-readthrough domain of $\mathrm{p} 89$ ), $\mathrm{p} 89$ (the readthrough domain of $\mathrm{p} 89$ identified as the putative RNA-dependent RNA polymerase), p14 (the pre-readthrough domain of p7A), p7A (the putative movement protein), and p42 (CP). Nucleotide and amino acid sequence identities of the five proteins of the two isolates were estimated at $97.4-99.5 \%$ and $97.7-100 \%$, respectively (Ohisima et al., 2000).

MNSV was first reported in muskmelon showing necrotic spot on the leaves (Kishi, 1966). The virus had narrow natural host ranges limited almost exclusively to members of the Cucurbitaceae (Furuki, 1981) and was transmitted through seeds and by the soil-inhabiting fungus Olpidium borovanus (Campbell, 1996; Hibi, 1986). Necrotic spot disease was reported from melon in Japan (Kishi, 1966) and in California, USA (Gonzalez-Garza et al., 1979), cucumber in the Netherlands (Bos et al., 1984), and watermelon in Grace (Avgelis, 1989).

In a survey on virus diseases occurring in cucurbits in 2001, muskmelon plants were noticed to have severe leaf and stem necrosis. The isolated virus from infected muskmelon was a strain of MNSV, designated MNSVMN. This paper presents the results of these studies.

\section{Materials and Methods}

Virus isolation and bioassay. MNSV-MN was detected from muskmelon (Cucumis melo cv. Alsnight) showing necrosis on the leaf and stem in a plastic house in Naju, southern region of Korea, in 2001. The virus was isolated through three single lesion transfers on the cotyledon of melon seedlings. The inoculum was prepared by grinding infected cotyledons 5 days after inoculation with mortar and pestle in 1:5 (w/v) of $0.01 \mathrm{M}$ phosphate buffer, $\mathrm{pH}$ 7.2. After mechanical inoculation using carborundum $(600$ mesh), the 12 plant species belonging to 21 cucurbit cultivars were maintained for visual inspection of virus symptoms in the greenhouse for at least 3 weeks (Table 2). The plants inoculated for host ranges were grown in a greenhouse at $25 \pm 2^{\circ} \mathrm{C}$. Tests for systemic symptomless infection were conducted by inoculating 
extracts from upper leaves to muskmelon cotyledons. The virus has been deposited in the Plant Virus GenBank.

DsRNA analysis. Viral double-stranded RNA (dsRNA) was extracted from the leaf tissues of the muskmelon systemically infected with MNSV-MN by the procedure of Morris and Dodds (1979). DsRNA of Rice dwarf virus was used as molecular size marker. DsRNA was analyzed by electrophoresis through $6 \%$ polyacrylamide (arcrylamide : bisacrylamide, 29:1) slab gel containing 1XTBE ( $1 \mathrm{M}$ Tris, $0.83 \mathrm{M}$ boric acid and $10 \mathrm{mM}$ EDTA, pH 8.0). The dsRNA bands were visualized by silver staining method (Bio-Rad manual).

RT-PCR amplification. Total nucleic acids were extracted from the infected leaves of muskmelon by the method of Choi et al. (1998). A pair of primers for detection of MMSV-MN was designed based on nucleotide sequence analysis of the reported MNSVs (GenBank AB044708; AB044292). The primer I (5'ATGCGTTTAACCATCGCCAT3') and the primer II (5TAGGCGAGGTAGGCGGTTTCA3') were designed to detect and amplify the CP gene of MNSV. Reverse transcriptase (RT) reaction was carried out with one cycle at $42^{\circ} \mathrm{C}$ for 45 minutes and 35 cycles of $\mathrm{PCR}$ amplification using the step program $\left(95^{\circ} \mathrm{C}, 45\right.$ seconds; $50^{\circ} \mathrm{C}, 60$ seconds; and $72^{\circ} \mathrm{C}, 60$ seconds) followed by a final extension at $72^{\circ} \mathrm{C}$ for 10 minutes. The amplified PCR products were digested with restriction enzyme MspI (Promega Corp.) and analyzed by electrophoresis in $1.5 \%$ agarose gel.

Cloning and sequencing of CP gene of MNSV. The cDNA of the CP gene of MNSV-MN was cloned into the pGEM-T-Easy vector (Promega). The nucleotide sequence was determined using a BigDye DNA sequencing kit (Perkin-Elmer Corp., Norwalk, CT, USA) on an ABI 377 DNA sequencer (PE Applied Biosystems, Foster City, CA USA). All sequences were analyzed using the DNASTAR program (Madison, Wis., USA). Homologies of nucleotide and amino acid sequences were performed using a BLAST in the GenBank database.

\section{Results and Discussion}

Incidence of MNSV disease in muskmelon. A survey on the occurrence of MNSV in muskmelon was done in Naju and Daejun in 2001 and 2002 growing seasons. Muskmelon plants naturally infected with MNSV showed severe leaf and stem necrosis (Fig. 1). Symptoms appeared on young leaves as chlorotic spots and developed into necrotic spots, often expanding to give large necrosis. Necrotic streaks on the stem and fruit stalk appeared and later, the entire plant withered. Seasonal disease incidence is shown in Table 1. The natural disease incidence of muskmelon cv. Alsnight was very low $(<1 \%)$ in 30 -day-old

Table 1. Virus disease incidence on muskmelon plants showing necrotic symptoms in the plastic house, 2001 and 2002

\begin{tabular}{|c|c|c|c|c|}
\hline \multirow{2}{*}{$\begin{array}{l}\text { Area }^{\mathbf{a}} \\
\text { investigated }\end{array}$} & \multirow{2}{*}{$\begin{array}{c}\text { Day after } \\
\text { transplanting }\end{array}$} & \multicolumn{2}{|c|}{ No. of plants } & \multirow{2}{*}{$\begin{array}{c}\% \\
\text { infection }\end{array}$} \\
\hline & & Investigated & Diseased & \\
\hline \multirow[t]{3}{*}{ Naju } & 15 & 650 & 6 & 0.9 \\
\hline & 40 & 650 & 66 & 10.2 \\
\hline & 130 & 650 & 456 & 70.2 \\
\hline Daejun & 30 & 530 & 3 & 0.6 \\
\hline
\end{tabular}

${ }^{\mathrm{a}}$ The investigation was conducted in Naju in 2001 and in Daejun in 2002.

${ }^{\mathrm{b}}$ Cultivar of muskmelon grown on rockwool in Naju and on soil culture in Daejun was Alsnight.

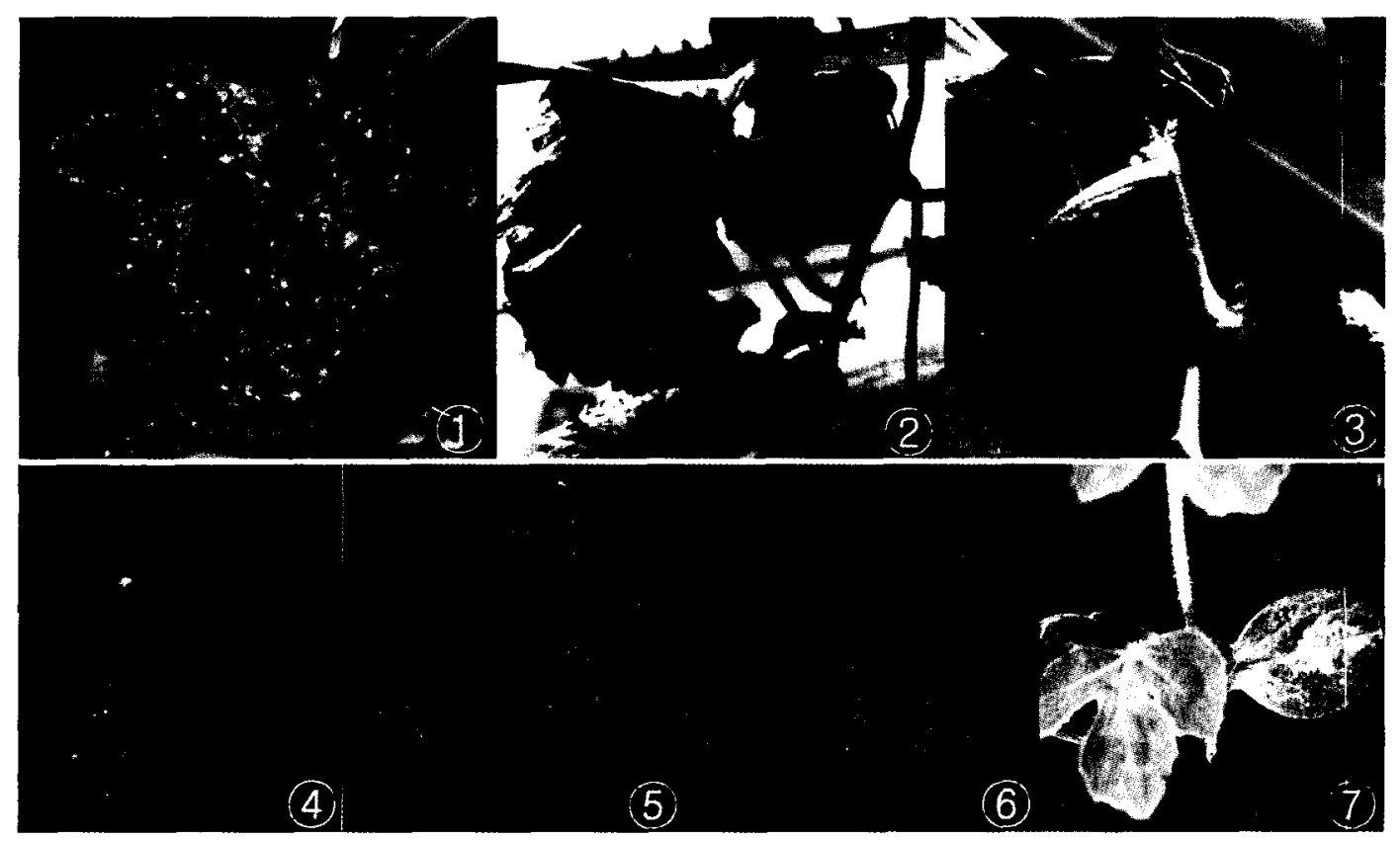

Fig. 1. Symptoms on muskmelon naturally infected with Melon necrotic spot virus (1, 2, and 3) and muskmelon (4), oriental melon (5), cucumber (6), and watermelon (7) mechanically inoculated with the virus. 
Table 2. Biological reactions of Melon necrotic spot virus-MN to different test plants

\begin{tabular}{|c|c|c|}
\hline \multirow{2}{*}{ Test plant } & \multicolumn{2}{|c|}{ Host reaction $^{\mathrm{a}}$} \\
\hline & Inoculated leaf & Upper leaf \\
\hline Chenopodium amaranticolor & - & $-(5 / 0)^{b}$ \\
\hline C. quinoa & - & $-(5 / 0)$ \\
\hline Datura stramonium & - & $-(5 / 0)$ \\
\hline Gomphorena globosa & - & $-(5 / 0)$ \\
\hline Nicotiana glutinosa & - & $-(5 / 0)$ \\
\hline N. clavelandii & - & $-(5 / 0)$ \\
\hline N. tabacum cv. Xanthi-nc & - & $-(5 / 0)$ \\
\hline Cucubita pepo cv. Taeyang & - & $-(10 / 0)$ \\
\hline C. moschata cv. Nongwooae & - & $-(10 / 0)$ \\
\hline Citrullus lantatus cv. Olympus & NS & $-(10 / 0)$ \\
\hline Cucumis sativus cv. Bagbong & CS & $-(10 / 0)$ \\
\hline C. melo cv. MVP & NS & NS $(16 / 5)$ \\
\hline cv. Best & NS & NS $(14 / 2)$ \\
\hline cv. Viva & NS & NS $(15 / 8)$ \\
\hline cv. Serhang & NS & NS $(14 / 14)$ \\
\hline cv. Happiness & NS & NS $(24 / 2)$ \\
\hline cv. Imperial & NS & NS $(19 / 17)$ \\
\hline cv. Saburu & NS & NS (13/13) \\
\hline cv. Party & NS & NS $(13 / 11)$ \\
\hline cv. Sunpower & NS & NS $(18 / 7)$ \\
\hline cv. Bagbo & NS & NS $(19 / 11)$ \\
\hline cv. Olimpic & NS & NS $(21 / 7)$ \\
\hline cv. VIP & NS & NS $(14 / 5)$ \\
\hline cv. Lomans & NS & NS (22/8) \\
\hline cv. Alsnight & NS & NS $(34 / 31)$ \\
\hline cv. Rui III & NS & NS $(18 / 18)$ \\
\hline cv. Salong & NS & NS (16/9) \\
\hline cv. Eunsung (oriental melon) & NS & NS $(72 / 5)$ \\
\hline
\end{tabular}

a Symptoms: - = no infection; NS = necrotic spot; $\mathrm{CL}=$ chlorotic spot.

${ }^{\mathrm{b}}$ Number of plants inoculated/number of plants systemically infected

plants after transplanting in the field but was high (70\%) in 130-day-old plants after transplanting. This abrupt spread of the viral disease might be due to transmission by contact between plants and/or by a vector, Olpidium radicale (Hibi, 1986), which has not been identified in this present experiment.

Host range. Out of 12 plant species mechanically inoculated with MNSV-MN, only three were susceptible: watermelon (Citrullus lantatus), cucumber (Cucumis sativus), and melon $(C$. melo). No symptoms were produced in Chenopodium amaranticolor, C. qunoa, Datura stramonium, Gomphorena globosa, Nicotiana spp., Cucurbita pepo, and C. moschata (Table 2). MNSV-MN was distinct from MNSV Cretan isolate infecting G. globosa (Avgelis, 1989). Melon was the only species which had systemic infection, while all other melon cultivars were not systemically infected. In oriental melon cv. Eunsung, 5 out of 73 inoculated plants produced systemic symptom while the other plants were locally infected. These results were similar to those of previous report which showed that cucumber and melon cultivars reacted severely with local

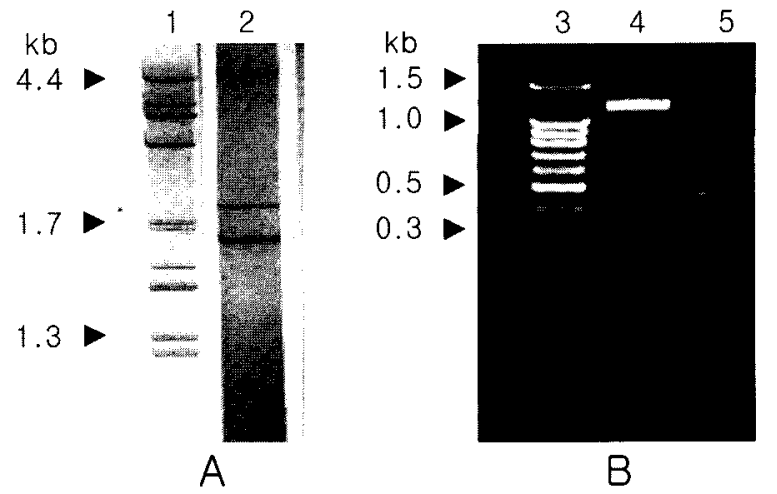

Fig. 2. DsRNA profiles of Melon necrotic spot virus-MN extracted from infected muskmelon (A) and amplified cDNA products obtained by RT-PCR with single pair of primers (B). Lane 1; Rice dwarf virus dsRNAs, 2 ; MNSV-MN dsRNA, $3 ; 1 \mathrm{~kb}$ DNA ladder, 4: the amplified DNA products of MNSV-MN, 5: the DNAs digested with $M s p$ I.

lesions, and that some even had systemic necrosis (Bos et al., 1984). It was presumed that systemic or local infection in identical cultivar will somehow be erratic under experimental conditions, or that there would be a difference in genotype resistance to the virus in each of the plants.

DsRNA analysis and RT-PCR. The dsRNAs extracted from melon infected with MNSV-MN are shown in Fig. 2A. Molecular sizes of MNSV-MN dsRNAs were estimated to be approximately $4.5,1.8$, and $1.6 \mathrm{kbp}$. Molecular size patterns of MNSV-MN dsRNAs were similar to those of the Douch isolate of MNSV (Riviere et al., 1989) and Japanese isolate of MNSV-S (Matsuo et al., 1991), while MNSV-NK and -NH (Matsuo et al., 1991) were reported to have two species of RNAs. The amplified DNA products of MNSV-MN RNA by RT-PCR showed approximately 1.2 $\mathrm{kb}$, covering full-length the viral CP gene (Fig. 2B). When the amplified DNA product was digested with $M s p I$, the DNA was divided into three fragments.

Sequence analysis of $\mathbf{C P}$ gene of MNSV-MN. The nucleotide sequence of MNSV-MN CP gene sequence and its deduced amino acid sequence are shown in Fig. 3. MNSV-MN CP gene consisted of 1,170 nucleotides which encoded 390 amino acid residues. The sequence has been deposited in the GenBank/EMBL databases under the accession number AB106106. The identity of MNSV-MN $\mathrm{CP}$ gene ranged from $84.0 \%$ to $94.6 \%$ with other MNSV isolates (GeneBank accession numbers AB044708, $\mathrm{AB} 044292, \mathrm{AF} 488692$, AY122286, D29662, and D12536) reported previously in the nucleotide level and from $90.8 \%$ to $94.9 \%$ in the amino acid level (Table 3).

This is the first report on the occurrence of MNSV in cultivated melon plants in Korea. This report provides information on the composition of the $\mathrm{CP}$ gene and the biological properties of MNSV-MN for detection and identification of the virus. 


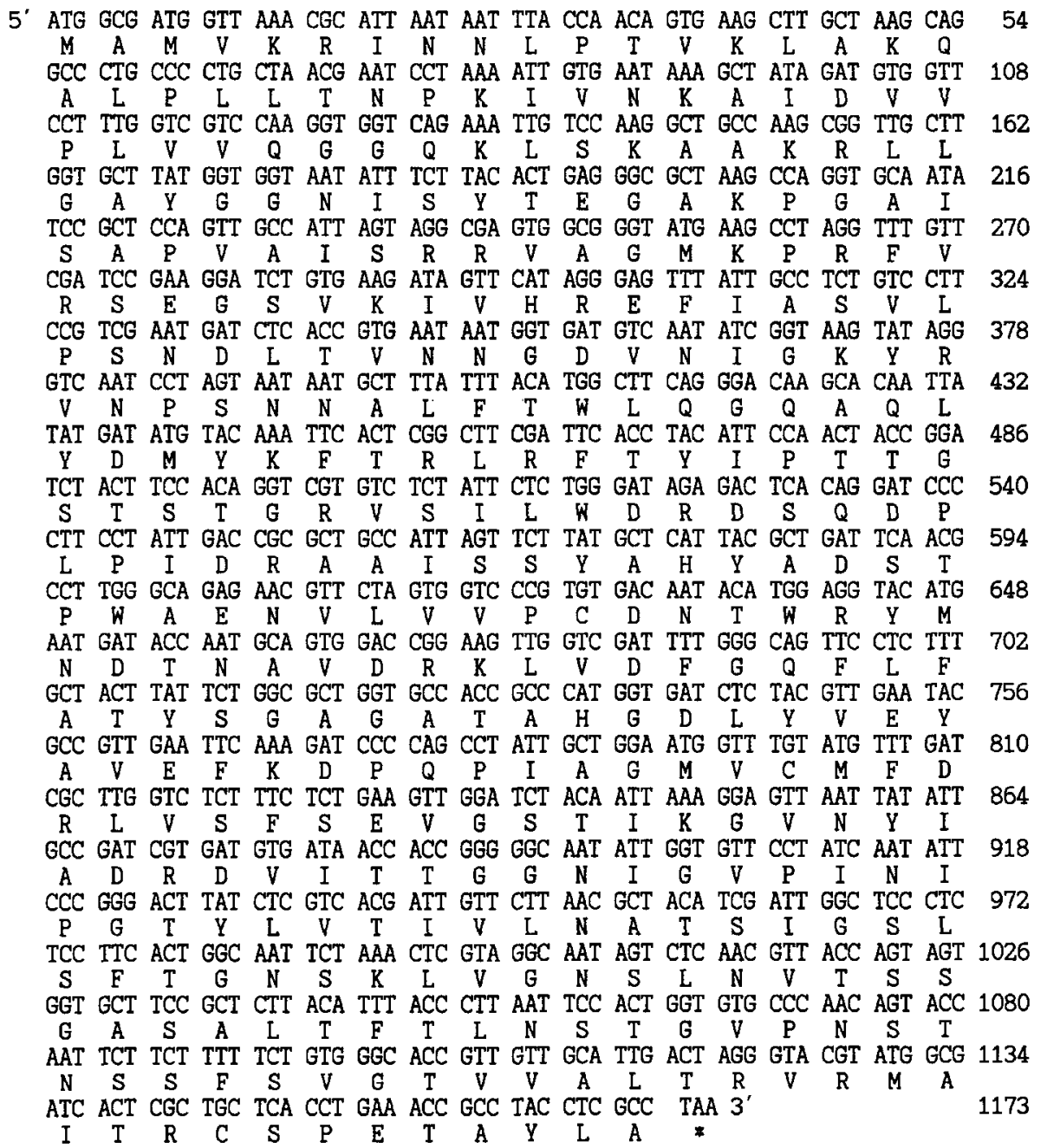

Fig. 3. Nucleotide sequences of the coat protein gene of Melon necrotic spot virus-MN and their deduced amino acid residues. The sequence has been deposited in the GenBank/EMBL databases under the accession number AB106106.

Table 3. Percentage sequence identities between the coat protein genes of Melon necrotic spot virus-MN and other MNSV isolates

\begin{tabular}{lcc}
\hline \hline \multirow{2}{*}{ MNSV source $^{\mathrm{a}}$} & \multicolumn{2}{c}{ Identity (\%) of coat protein } \\
\cline { 2 - 3 } & Nucleotide & Amino acid \\
\hline AB044708 & 94.6 & 94.9 \\
AB044292 & 94.5 & 94.6 \\
AF488692 & 89.2 & 92.9 \\
AY122286 & 84.0 & 90.8 \\
D29662 & 93.6 & 94.9 \\
D12536 & 89.1 & 91.5 \\
\hline
\end{tabular}

${ }^{a}$ Homology of nucleotide and amino acid sequences of MNSV coat protein genes were performed using a BLAST in the GenBank database.

\section{Acknowledgments}

This study was supported by a grant from BioGreen 21 program, the Rural Development of Administration in Republic of Korea.

\section{References}

Avgelis, A. D. 1989. Watermelon necrosis caused by a strain of melon necrotic spot virus. Plant Pathol. 38:61 8-622.

Bos, L., Van Dost, H. J. M., Huttigna, H. and Maat, D. Z. 1984. Further characterization of melon necrotic spot virus causing severe diseases in glasshouse cucumbers in the Netherlands and its control. Neth. J. Plant Pathol. 90:55-69.

Choi, J. K., Kim, H. J., Hong, J. S., Kim, D. W. and Lee, S. Y. 1998. Identification and differentiation of cucumber mosaic virus isolates in Korea. Korean J. Plant Pathol. 14:7-12.

Compbell, R. N. 1996. Fungal transmision of plant viruses. Annu. Rev. Phytopathol. 34:87-108.

Hibi, T. 1986. Melon necrotic spot virus. CMI/AAB Descriptions of Plant Viruses, no. 302, Kew, United Kingdom.

Furuki, 1981. Epidemiological studies on melon necrotic spot. Tech. Bull. Shizuoka Agric. Exp. Stn. 14:1-94.

Gonzalez-Garza, R., Gumpz, D. J., Kishaba, A. N. and Bohn, G. W. 1979. Identification, seed transmission, and host range 
pathogenicity of a California isolate of melon necrotic spot vinus. Phytopathology 69:340-345.

Kishi, K. 1966. Necrotic spot of melon, a new virus disease. Ann. Phytopath. Soc. Japan 32:138-144.

Matsuo, K., Kameya-Iwaki, M. and Ota, T. 1991. Two new strains of melon necrotic spot virus. Ann. Phytopath. Soc. Japan 57:558-567.

Morris, T. J. and Carrington, J. C. 1988. Carnation mottle virus and viruses with similar properties. In: The Plant Viruses, vol. 3, pp. 73-112. ed. R. Koenig. Plenum Press, New York.

Morris, T. J. and Dodds, J. A. 1979. Isolation and analysis of double-stranded RNA from virus-infected plant and fungal tissue.
Phytopathology 69:854-858.

Ohisima, K., Ando, T., Motomura, N., Matsuo, K. and Sako, N. 2000. Comparative study on genomes of two Japanese Melon necrotic spot virus isolates. Acta Virologica 44:309-314.

Rochon, D. M. and Tremaine, J. H. 1989. Complete nucleotide sequence of the cucumber necrosis virus genome. Virology 169:251-259.

Van Regenmomortel, M. H. V., Fauquet, C. M., Bishop, D. H. L., Carstens, E., Estes, M. K., Lemon, S., Maniloff, J., Mayo, M. A., McGeoch, D., Pringle, C. R. and Wickner, R. B. 2000. Virus Taxnomy. Seventh Report of the International Committee on Taxonomy of Viruses. Academic Press, New York. 